\author{
Praca poglądowa/Review paper
}

\title{
Genetyczne podłoże nowotworów tarczycy - wybrane zagadnienia
}

\section{Genetic background of thyroid carcinomas - selected issues}

\author{
Joanna Wróblewska ${ }^{1}$, Andrzej Marszałek ${ }^{1}$ \\ ${ }^{1}$ Departments of Pathology, Poznan University Medical Sciences and Greater Poland Cancer Center, Poznan, Poland
}

\section{Streszczenie}

Nowotwory tarczycy są najczęściej występującymi wśród nowotworów układu wewnątrzwydzielniczego. W ciągu ostatnich dekad liczba nowych zachorowań znacząco wzrosła i wciąż wykazuje tendencję wzrostową. U podstaw choroby nowotworowej leżą zmiany zachodzące w komórkach na poziomie molekularnym, głównie mutacje somatyczne w określonych onkogenach lub genach supresorowych. Analiza profilu molekularnego $\mathrm{w}$ zakresie mutacji somatycznych występujących w genach związanych z nowotworami tarczycy pozwala na poszerzenie wiedzy na temat molekularnych podstaw nowotworzenia i poznanie roli ich genetycznego podłoża w rozwoju choroby, jej progresji i rokowaniu powodzenia terapii. Mutacje w genach z rodziny RAS (NRAS, KRAS, HRAS) związane są najczęściej z typem pęcherzykowym nowotworu tarczycy, ale wykrywane są także w przypadku typu anaplastycznego. Mutacje w genie BRAF związane są natomiast z typem brodawkowym, ale również mogą występować w typie anaplastycznym. Mutacje w genie TP53 lub regionie promotorowym genu TERT związane są z większą agresywnością nowotworu, przerzutami i gorszym rokowaniem dla chorego.

\footnotetext{
Abstract

Adres do korespondencji

Joanna Wróblewska

Departments of Pathology

Wielkopolskie Centrum Onkologii, ul. Garbary 15, 61-866 Poznań, Polska

Telefon. +48600 597174

e-mail: joanna.wroblewska@wco.pl
}

Thyroid neoplasms are the most common tumors among endocrine system. Over the last decades, the number of new cases has increased significantly and continues to show an upward trend. At the basis of the neoplastic disease are changes occurring in cells at the molecular level, mainly somatic mutations in certain oncogenes or suppressor genes. Molecular profile analysis in the field of somatic mutations in the genes associated with thyroid cancer allows to broaden knowledge about the molecular basis of cancer and to understand the role of their genetic basis in the development of the disease, its progression and prognosis of successful therapy. Mutations in genes from the RAS family (NRAS, KRAS, HRAS) are most often 
associated with the follicular type of thyroid cancer, but are also detected in the case of the anaplastic type. However, mutations in the BRAF gene are associated with papillary type, but may also occur in the anaplastic type. Mutations in the promoter region of the TERT gene are associated with higher tumor aggressiveness, metastases and worse prognosis for the patients.

Stowa kluczowe: nowotwory tarczycy, mutacje somatyczne, protoonkogeny, geny supresorowe

Keywords: thyroid carcinomas, somatic mutations, protooncogenes, suppressor genes

\section{Wybrane nowotwory tarczycy - etiologia i cechy charakterystyczne}

Pierwotne nowotwory tarczycy stanowią największą grupę nowotworów układu endokrynnego u dorosłych. Chociaż stanowią one zaledwie $2 \%$ wszystkich nowych przypadków rocznie, to w ciągu ostatnich dekad zaobserwowano ponad trzykrotny wzrost zachorowań, co plasuje nowotwory tarczycy wśród chorób nowotworowych, których liczba nowych przypadków wzrasta najszybciej [1]. Do czynników ryzyka zaliczamy płeć żeńską (kobiety chorują statystycznie trzykrotnie częściej niż mężczyźni), wiek powyżej 40 lat, niedobór jodu, ekspozycja na promieniowanie jonizujące, szczególnie w rejonie głowy i szyi, oraz czynniki genetyczne. Związek między zapaleniem tarczycy typu Hashimoto, najczęstszą chorobą autoimmunologiczną dotykająca tego narządu, a wystąpieniem raka tarczycy nie został jednoznacznie potwierdzony [2, 3]. Większość typów histologicznych raka tarczycy powstaje z komórek pęcherzykowych, budujących tkankę gruczołową. Do tych typów zaliczamy raka brodawkowatego, pęcherzykowatego oraz anaplastycznego. Rak rdzeniasty tarczycy rozwija się z komórek $\mathrm{C}$, produkujących kalcytoninę. Rokowanie i przebieg choroby zależne są od typu histologicznego nowotworu [4].

Rak brodawkowaty tarczycy (ang. papillary thyroid carcinoma, PTC) jest najczęstszym, zróżnicowanym typem nowotworów tarczycy, występującym w około 85-90\% przypadków. Rokowanie w przypadku wczesnego rozpoznania choroby jest bardzo dobre z 5-letnim przeżyciem sięgającym 95\%. Niezdiagnozowany rak brodawkowaty rozprzestrzenia się drogą układu limfatycznego, tworząc przerzuty w obrębie narządu oraz okolicznych węzłów chłonnych. Wznowa występuje u 15\% chorych, natomiast występowanie przerzutów odległych dotyczy tylko 5\% przypadków $[1,5]$.

Drugą dużą grupą zróżnicowanych nowotworów złośliwych tarczycy są raki pęcherzykowate (ang. follicular thyroid carcinoma, FTC), stanowiące około 5\% wszystkich przypadków. FTC, w przeciwieństwie do PTC, wykazuje tendencje do rozprzestrzeniania się poprzez układ krwionośny, tworząc odległe przerzuty głownie w płucach i kościach. Zarówno PTC jak i FTC cechuje wolny wzrost guza nowotworowego. Rokowanie jest podobne jak w przypadku PTC u chorych w podobnym wieku i na podobnym stopniu zaawansowania choroby [4].

Rak anaplastyczny tarczycy (ang. anaplastic thyroid carcinoma, ATC) jest niezwykle rzadkim i najbardziej agresywnym typem nowotworów tarczycy. Histologicznie jest to najmniej zróżnicowany typ nowotworu, o bardzo szybkim wzroście i inwazyjności. Jednocześnie stanowi on zaledwie 1-2\% wszystkich guzów tarczycy wywodzących się z komórek pęcherzykowych [4]. Jego występowanie wiąże się z bardzo złym rokowaniem i wysoką śmiertelnością. Mediana przeżycia chorych z ATC wynosi tylko 5-6 miesięcy, a tylko 10-15\% pacjentów przeżywa 2 lata po diagnozie [6]. Według American Joint Committee on Cancer (AJCC) , wszystkie przypadki ATC są klasyfikowane jako IV stopień zaawansowania choroby, niezależnie od statusu TNM. Przerzuty odległe do płucach, kości i mózgu, które rozprzestrzeniają się przez układ krwionośny, występują w 50\% przypadków w chwili rozpoznania, a u kolejnych 25\% chorych rozwiną się w trakcie choroby [7].

\section{Leczenie wybranych nowotworów tarczycy}

Według zaleceń Polskiego Towarzystwa Onkologii Klinicznej standardowa terapia jest uzależniona od typu i stopnia zaawansowania nowotworu. Leczeniem z wyboru jest zabieg chirurgiczny obejmujący częściową lub całkowitą resekcję tarczycy oraz okolicznych węzłów chłonnych. Radioterapia izotopem jodu I ${ }^{131}$ 
stosowana jest w przypadku nieoperacyjnych nowotworów tarczycy (z wyłączeniem typu anaplastycznego) oraz w celu usunięcia ewentualnych ognisk nowotworowych pozostałych po zabiegu chirurgicznym lub przerzutów. W przypadku raka anaplastycznego tarczycy stosuje się leczenie chirurgiczne skojarzone $\mathrm{z}$ radioterapią i chemioterapią, co nieznacznie poprawia medianę czasu przeżycia chorych [8]. Ze względu na występowanie charakterystycznych cech molekularnych ATC trwają badania mające na celu wykorzystanie leków ukierunkowanych molekularnie takich jak inhibitory kinaz tyrozynowych w leczeniu chorych. Jak dotąd żaden z leków wykorzystywanych w chemioterapii celowanej nie został zatwierdzony w terapii raka anaplastycznego tarczycy [9].

\section{Podłoże molekularne wybranych nowotworów tarczycy}

Rozwój narzędzi biologii molekularnej pozwolił na kompleksową analizę molekularnego podłoża nowotworów tarczycy oraz wytypowanie cech charakterystycznych dla genomów raków brodawkowatego, pęcherzykowatego i anaplastycznego. PTC i FTC charakteryzują się stosunkowo niską liczbą mutacji somatycznych, co może przekładać się na dobrą odpowiedź chorego na leczenie i dobre rokowanie na pełne wyleczenie. W projekcie The Cancer Genome Atlas (TCGA) zidentyfikowano dwa podtypy molekularne PTC, u podłoża których leży występowanie mutacji somatycznych w genach BRAF (ang. BRAF p.V6ooE-like) lub $\mathrm{N} / \mathrm{H}$ / KRAS (ang. RAS-like). Nowotwory z sygnaturą BRAF p.V6ooE-like charakteryzują się zwiększonym poziomem aktywacji szlaku sygnałowego kinaz aktywowanych mitogenami (ang. mitogen-activated protein kinases, MAPK) i reprezentują bardziej klasyczne raki brodawkowate. Zmiany genetyczne charakterystyczne dla tego podtypu molekularnego obejmują, oprócz mutacji aktywującej w kodonie 600 genu $B R A F$, także rearanżacje $R E T-P T C, N T R K$ i $A L K$. Podtyp $R A S$-like charakteryzuje się niższym poziomem aktywacji szlaku sygnałowego MAPK i charakteryzuje nowotwory różnicujące się w stronę fenotypu pęcherzykowatego. Zmiany genetyczne obejmują głównie mutacje aktywujące w genach $N R A S, H R A S$ i $K R A S$, oraz niewielka liczbę niekanonicznych mutacji genu $B R A F$ (innych niż zlokalizowane w kodonie 600) [1, 4]. FTC są głównie charakteryzowane przez mutacje somatyczne w genach $N R A S, H R A S$ i $K R A S$ oraz rearażacjach genu PPARG [8]. Jednakże, kompleksowe badania molekularne wykazały dużą różnorodność genów ulegających mutacji, takich jak PTEN, NCOA2, CHEK2, FOXO4 i wiele innych. Sugeruje to, że u podłoża FTC może leżeć wiele różnych zdarzeń molekularnych i wskazanie genu specyficznego dla tego typu nowotworów, jak $B R A F$ w PTC, może nie być możliwe [10]. Anaplastyczny rak tarczycy charakteryzuje się bardzo dużą liczbą współistniejących mutacji somatycznych w porównaniu do typu pęcherzykowego i brodawkowatego, sięgającą nawet 100 mutacji somatycznych na próbkę [11]. Ten typ nowotworu wywodzi się z dobrze zróżnicowanych raków tarczycy, cechuje go wspólny profil mutacji z FTC i PTC, z fenotypem podobnym do $B R A F$, niezależnie od występowania mutacji kierującej (ang. driver mutation) [12]. Najczęściej występujące mutacje obejmują geny TP53, BRAF, RAS, PTEN, PIK3CA, CDKN2A, EF1AX i region promotorowy genu TERT. Wynikiem tego jest jednoczesna deregulacja wielu ścieżek sygnałowych w przypadkach raka anaplastycznego tarczycy [12$14]$.

\section{Wybrane geny związane z nowotworami tarczycy - opis i funkcja}

Białka z rodziny $R A S$ (kodowane przez geny $N R A S, K R A S$ i $H R A S$ ) pełnią funkcję enzymów wiążących i hydrolizujących GTP - GTPaz, uczestniczących w przekazywaniu sygnału i aktywacji ścieżek sygnałowych $M A P K$ i PI3K/AKT/mTOR. Regulują ekspresję genów związanych z proliferacją, wzrostem, adhezją i migracją komórek oraz apoptozą. Mutacje aktywujące występujące w obrębie tych genów (ekson 2, 3 i 4) mają bezpośredni związek z rozwojem nowotworów jelita grubego, trzustki, płuc oraz tarczycy. W wyniku mutacji w domenie GTPazy lub domenie wiążącej GTP powodują zablokowanie białka w jego aktywnej formie i stałe pobudzanie ścieżki sygnałowej MAPK/Erk, niezależnie od czynników zewnętrznych. W nowotworach tarczycy najczęściej występujące mutacje zlokalizowane są w egzonie 3 genu NRAS, głownie w kodonie 61 (ok 20-30\%), natomiast mutacje w genach KRAS i HRAS występują w około 10\% wszystkich przypadków $[15,16]$.

Gen $B R A F$ koduje białko z rodziny kinaz serynowo/treoninowych, biorące udział w przekazywaniu sygnału na ścieżce MAPK/Erk, regulując wzrost i proliferację komórek. Mutacje somatyczne genu BRAF 
związane są z występowaniem czerniaka złośliwego, nowotworów jelita grubego, płuc, chłoniaków, białaczek oraz nowotworów tarczycy. Mutacja aktywująca dotyczy głownie kodonu 6oo w eksonie 15 (95\% przypadków) oraz w niewielkim stopnie kodonu 601. Występowanie mutacji powoduje zmianę konformacji białka skutkującą zablokowanie jej w formie stale aktywnej, co powoduje stałe fosforylowanie i aktywowanie kinazy MAP2K1. Podobnie jak w przypadku mutacji w genach $R A S$ skutkuje to stałym pobudzaniem ścieżki sygnałowej MAPK/Erk, niezależnie od czynników zewnątrzkomórkowych [5, 15, 17].

Gen TERT koduje podjednostkę kompleksu telomerazy, enzymu który dzięki aktywności odwrotnej transkryptazy dodaje powtarzającą się sekwencję TTAGGG na 3' końcu replikowanego DNA. Sekwencja ta wraz z kompleksem białek tworzy telomer, kompleks pozwalający na utrzymanie integralności chromosomów podczas kolejnych cykli replikacji DNA związanej z podziałami komórkowymi. Mutacje aktywujące w regionie promotorowym genu głównie w pozycjach -124 (C228T) oraz -146 (C250T) powodują powstanie dodatkowego miejsca wiązania czynników transkrypcyjnych, co skutkuje zwiększoną ekspresją genu oraz zwiększoną aktywnością kompleksu telomerazy, leżącymi u podstaw procesu nowotworzenia. Występowanie mutacji skorelowane jest z bardziej agresywną postacią nowotworu, gorszym rokowaniem, tworzeniem przerzutów, wznowy i niepowodzeniem terapii, oraz z większą śmiertelnością chorych [18].

Gen PIK3CA koduje jednostkę katalityczną kinazy 3 fosfatydyloinozytolu (ang. phosphoinositide 3-kinases, PI3K), uczestniczącej w przekazywaniu sygnałów w kaskadzie PI3K-PTEN-AKT, jednej z głównych ścieżek regulujących wzrost, proliferację, metabolizm, przeżycie i angiogenezę komórek. Mutacje aktywujące dotyczą głownie eksonów 9 i 20, kodujących odpowiednio domenę helikalną oraz domenę o aktywności kinazy. Skutkuje to stałą aktywacją białka oraz stałym pobudzaniem ścieżki sygnałowej PI3K-PTEN-AKT [20].

Gen supresorowy PTEN koduje fosfatazę, która negatywnie reguluje aktywność ścieżki PI3K-PTENAKT, poprzez defosforylację trifosforanów inozytolu (PIP3) do difosforanów inozytolu (PIP2). Mutacje inaktywujące powodują utratę funkcji białka i brak negatywnej regulacji ścieżki PI3K-PTEN-AKT, prowadząc do zwiększonej proliferacji komórek i zmniejszonej apoptozy [21].

Białko RET jest transbłonowym receptorem kinaz tyrozynowych, uczestniczących w przekazywaniu sygnałów na ścieżce sygnałowej MAPK oraz PI3K-PTEN-AKT [22]. Ulega ekspresji głownie w komórkach $\mathrm{C}$ produkujących kalcytoninę, brak go w komórkach pęcherzykowatych tarczycy. Z tego względu mutacje somatyczne dotyczą głównie raka rdzeniastego tarczycy. W przypadku raka brodawkowatego dochodzi do translokacji w obrębie i pomiędzy chromosomami, co skutkuje powstaniem białka fuzyjnego, które traci swoją domenę transbłonową. Białko to traci swoją błonową lokalizację i stale znajduje się w cytoplazmie komórki, powodując deregulację szlaków sygnałowych MAPK oraz PI3K-PTEN-AKT. Fuzja dotyczy zawsze domeny kinazowej genu RET, natomiast drugi gen (gen aktywujący) może być różny. Do tej pory zidentyfikowano 13 typów rearanżacji RET/PTC, z czego RET/PTC1, RET/PTC2 oraz RET/PTC3 są najczęstsze. Występowanie rearanżacji genu $R E T$ jest związane z wiekiem zachorowania (znacznie częstszy u młodych chorych) oraz rozwojem raka brodawkowatego tarczycy w wyniku ekspozycji na promieniowanie jonizujące [23].

Rearanżacje w obrębie genów $P A X 8 / P P A R G$ dotyczą głównie raków pęcherzykowych tarczycy. Gen PPARG koduje białko receptora jądrowego, który reguluje ekspresję genów odpowiedzialnych za metabolizm glukozy oraz kwasów tłuszczowych. Białko PAX8 jest jednym z czynników transkrypcyjnych, regulujących syntezę hormonów tarczycy. W wyniku fuzji obejmującej większość sekwencji kodującej obu genów, powodując stałą ekspresję białka fuzyjnego, z zachowaniem funkcji obu białek, co prowadzi do deregulacji procesów metabolicznych komórki. Rearanżacje $P A X 8 / P P A R G$ są również skorelowane z niższym wiekiem zachorowania oraz ekspozycją na promieniowanie jonizujące [24].

\section{Podsumowanie}

Poznanie molekularnego podłoża nowotworów tarczycy wniosło znaczący wkład w zrozumienie procesów odpowiedzialnych za rozwój choroby, jej przebieg oraz rokowanie. Wyniki wysokoprzepustowych analiz genomu komórek nowotworowych zestawione z przebiegiem choroby i odpowiedzią na leczenie umożliwiają określenie przydatności danych genów i związanych z nimi mutacji jako biomarkerów prognostycznych $\mathrm{w}$ chorobie nowotworowej. Ponadto, wsparcie rutynowej diagnostyki, opierającej się na rozpoznaniu histopatologicznym, analizami molekularnymi pozwala na rozstrzygnięcie wątpliwości oraz może być wskazaniem do wdrożenia bądź też zaniechania radykalnego leczenia. 


\section{Konflikt interesu/ Conflict of interest}

Nie występuje / None

\section{Finansowanie/ Financial suport}

Artykuł finansowany w ramach grantu wewnętrznego Wielkopolskiego Centrum Onkologii w Poznaniu, nr 11/04/2017/ZP/WCO/0015. / This work was supported by the Greater Poland Cancer Centre intramural grant no 11/04/2017/ZP/WCO/0015.

\section{Etyka/ Ethics}

Treści przedstawione w artykule są zgodne z zasadami Deklaracji Helsińskiej, dyrektywami EU oraz ujednoliconymi wymaganiami dla czasopism biomedycznych.

\section{Piśmiennictwo / References}

[1] Agrawal, N., et al., Integrated Genomic Characterization of Papillary Thyroid Carcinoma. Cell, 2014. 159(3): p. 676-690.

[2] Lai, X., et al., A meta-analysis of Hashimoto's thyroiditis and papillary thyroid carcinoma risk. Oncotarget, 2017. 8(37): p. 62414-62424.

[3] Resende de Paiva, C., et al., Association between Hashimoto's Thyroiditis and Thyroid Cancer in 64,628 Patients. Frontiers in oncology, 2017. 7: p. 53-53.

[4] Acquaviva, G., et al., Molecular pathology of thyroid tumours of follicular cells: a review of genetic alterations and their clinicopathological relevance. Histopathology, 2018. 72(1): p. 6-31.

[5] Rusinek, D., et al., Coexistence of TERT Promoter Mutations and the BRAF V6ooE Alteration and Its Impact on Histopathological Features of Papillary Thyroid Carcinoma in a Selected Series of Polish Patients. Int J Mol Sci, 2018. 19(9).

[6] Molinaro, E., et al., Anaplastic thyroid carcinoma: from clinicopathology to genetics and advanced therapies. Nature Reviews Endocrinology, 2017. 13: p. 644.

[7] Tuttle, R.M., B. Haugen, and N.D. Perrier, Updated American Joint Committee on Cancer/Tumor-NodeMetastasis Staging System for Differentiated and Anaplastic Thyroid Cancer (Eighth Edition): What Changed and Why? Thyroid : official journal of the American Thyroid Association, 2017. 27(6): p. 751756.

[8] Rusinek, D., et al., Current Advances in Thyroid Cancer Management. Are We Ready for the Epidemic Rise of Diagnoses? Int J Mol Sci, 2017. 18(8).

[9] Glaser, S.M., et al., Anaplastic thyroid cancer: Prognostic factors, patterns of care, and overall survival. Head Neck, 2016. 38 Suppl 1: p. E2083-90.

[10] Swierniak, M., et al., Somatic mutation profiling of follicular thyroid cancer by next generation sequencing. Molecular and Cellular Endocrinology, 2016. 433: p. 130-137.

[11] Kunstman, J.W., et al., Characterization of the mutational landscape of anaplastic thyroid cancer via whole-exome sequencing. Hum Mol Genet, 2015. 24(8): p. 2318-29.

[12] Landa, I., et al., Genomic and transcriptomic hallmarks of poorly differentiated and anaplastic thyroid cancers. J Clin Invest, 2016. 126(3): p. 1052-66.

[13] Bonhomme, B., et al., Molecular Pathology of Anaplastic Thyroid Carcinomas: A Retrospective Study of 144 Cases. Thyroid, 2017. 27(5): p. 682-692.

[14] Tiedje, V., et al., NGS based identification of mutational hotspots for targeted therapy in anaplastic thyroid carcinoma. Oncotarget, 2017. 8(26): p. 42613-42620.

[15] Fakhruddin, N., et al., BRAF and NRAS Mutations in Papillary Thyroid Carcinoma and Concordance in BRAF Mutations Between Primary and Corresponding Lymph Node Metastases. Scientific Reports, 2017. 7(1): p. 4666.

[16] Xing, M., Clinical utility of RAS mutations in thyroid cancer: a blurred picture now emerging clearer. 
BMC Med, 2016. 14: p. 12.

[17] Czarniecka, A., M. Oczko-Wojciechowska, and M. Barczyński, BRAF V6ooE mutation in prognostication of papillary thyroid cancer (PTC) recurrence. Gland surgery, 2016. 5(5): p. 495-505.

[18] Liu, R. and M. Xing, TERT promoter mutations in thyroid cancer. Endocr Relat Cancer, 2016. 23(3): p. R143-55.

[19] Manzella, L., et al., New Insights in Thyroid Cancer and p53 Family Proteins. International journal of molecular sciences, 2017. 18(6): p. 1325.

[20] Xing, M., Genetic alterations in the phosphatidylinositol-3 kinase/Akt pathway in thyroid cancer. Thyroid : official journal of the American Thyroid Association, 2010. 20(7): p. 697-706.

[21] Xu, B. and R. Ghossein, Genomic Landscape of poorly Differentiated and Anaplastic Thyroid Carcinoma. Endocr Pathol, 2016. 27(3): p. 205-12.

[22] Arighi, E., M.G. Borrello, and H. Sariola, RET tyrosine kinase signaling in development and cancer. Cytokine Growth Factor Rev, 2005. 16(4-5): p. 441-67.

[23] Khan, M.S., et al., RET/PTC Gene Rearrangements in Thyroid Carcinogenesis: Assessment and ClinicoPathological Correlations. Pathol Oncol Res, 2018.

[24] Armstrong, M.J., et al., PAX8/PPARy rearrangement in thyroid nodules predicts follicular-pattern carcinomas, in particular the encapsulated follicular variant of papillary carcinoma. Thyroid : official journal of the American Thyroid Association, 2014. 24(9): p. 1369-1374. 